\title{
ENDOCRINE TUMORS
}

\section{BRAF V600E mutations in papillary craniopharyngioma}

\author{
Priscilla K Brastianos ${ }^{1}$ and Sandro Santagata ${ }^{2,3,4}$ \\ ${ }^{1}$ Division of Neuro-Oncology, Massachusetts General Hospital, Harvard Medical School, Boston, \\ Massachusetts 02114, USA, ${ }^{2}$ Department of Cancer Biology, Dana-Farber Cancer Institute, Harvard Medical School, \\ Boston, Massachusetts 02215, USA, ${ }^{3}$ Department of Pathology, Brigham and Women's Hospital, \\ Harvard Medical School, Boston, Massachusetts, 77 Avenue Louis Pasteur, Boston, Massachusetts 02115, USA and \\ ${ }^{4}$ Department of Pathology, Boston Children's Hospital, Harvard Medical School, Boston, Massachusetts 02115, USA
}

\author{
Correspondence \\ should be addressed \\ to S Santagata \\ Email \\ ssantagata@ \\ bics.bwh.harvard.edu
}

\section{Abstract}

Papillary craniopharyngioma (PCP) is an intracranial tumor that results in high levels of morbidity. We recently demonstrated that the vast majority of these tumors harbor the oncogenic BRAF V600E mutation. The pathologic diagnosis of PCP can now be confirmed using mutation specific immunohistochemistry and targeted genetic testing. Treatment with targeted agents is now also a possibility in select situations. We recently reported a patient with a multiply recurrent PCP in whom targeting both $B R A F$ and MEK resulted in a dramatic therapeutic response with a marked anti-tumor immune response. This work shows that activation of the MAPK pathway is the likely principal oncogenic driver of these tumors. We will now investigate the efficacy of this approach in a multicenter phase II clinical trial. Post-treatment resection samples will be monitored for the emergence of resistance mechanisms. Further advances in the non-invasive diagnosis of PCP by radiologic criteria and by cell-free DNA testing could someday allow neo-adjuvant therapy for this disease in select patient populations.

\section{Background}

Craniopharyngiomas are uncommon epithelial neoplasms that arise above the sella turcica of the skull base, in the suprasellar, infundibulotuberal, and third ventricular areas of the brain $(1,2,3)$. Despite their benign histologic appearance, these tumors pose many clinical challenges $(4,5,6)$. The tumors arise in proximity to critical structures and can compress or infiltrate these vital neurological areas $(4,5,6,7)$. Visual defects, pan-hypopituitarism, cognitive deficits, personality changes, hyperphagia and morbid obesity are common complications that result not only from the growth of the tumor but also often as a consequence of treatment with surgery, radiation, or both $(4,5,6,7,8,9,10,11)$. Moreover, scarring and reactive changes occur following surgical resection and radiation treatment. As a result, resecting recurrent tumors is fraught with difficulties. Patient management is further complicated by a lack of effective systemic chemotherapies (12) and by variations in clinical practice algorithms (13).

There are two histopathologic variants of craniopharyngioma. Adamantinomatous craniopharyngioma (ACP)

\section{Invited Author's profile}

S Santagata, MD PhD is an Assistant Professor in pathology at Harvard Medical School and practices neuropathology and molecular pathology at Brigham and Women's Hospital and Boston Children's Hospital. His research focuses on understanding a fundamental challenge in tumor biology: how tumor cells develop their most aggressive behaviors and the mechanisms that they use to resist even the most sophisticated therapeutic regimens.

(C) 2016 European Society of Endocrinology Printed in Great Britain
Published by Bioscientifica Ltd. 
occurs in both children and adults, and papillary craniopharyngioma (PCP) occurs almost exclusively in adults. These variants have distinct histologic features $(1,14,15)$.

When resection specimens are large and abundant, and well-preserved tumor epithelium is present, classification is routine on H\&E stained sections $(1,14,15)$. ACP has epithelium that grows in cords, lobules, and whorls, with palisading peripheral columnar epithelium and loosely arranged epithelium called stellate reticulum. 'Wet' keratin is a hallmark of this variant. PCP has welldifferentiated monomorphic squamous epithelium covering fibrovascular cores with thin capillary blood vessels and scattered immune cells including macrophages and neutrophils. The epithelium lacks surface maturation and there is no 'wet' keratin $(14,15)$.

In some craniopharyngioma resection specimens, however, the epithelium is sparse or absent and establishing a definite diagnosis can be challenging (16). Some specimens for instance have prominent reactive changes with marked granulomatous inflammation, cholesterol clefts, and prominent lymphocytic inflammation. On small biopsies, some PCP can be difficult to distinguish from other suprasellar and infundibulotuberal masses such as non-neoplastic Rathke's cleft cysts $(16,17)$. These cysts are often lined by ciliated cuboidal or columnar epithelium, but prominent squamous metaplasia can also occur, resembling the epithelium of PCP (17).

Our recent genomic characterization of ACP and PCP revealed that each subtype of craniopharyngioma harbors highly recurrent activating mutations (18). We observed that over $90 \%$ of ACP have mutations in CTNNB1 (18) consistent with other studies demonstrating that mutations in exon 3 of the gene encoding $\beta$-catenin and activation of the WNT pathway are important in the tumorigenesis of ACP $(19,20,21,22,23)$. Unexpectedly, we found that over $90 \%$ of PCP have BRAF V600E mutations (18). CTNNB1 and BRAF alterations were mutually exclusive, clonal, and specific to each subtype. This propitious finding has important implications for the diagnosis of PCP and the clinical management of some patients with this tumor.

\section{Diagnostic evaluation of craniopharyngioma}

The most immediate clinical impact of our findings is on everyday practical pathology diagnostics. Pathologists can now use immunohistochemistry (IHC) to guide diagnostic classification of suprasellar lesions. This is particularly helpful in specimens that are minute or have scant epithelium. In cells that lack mutations in CTNNB1 such as in PCP, the $\beta$-catenin protein is localized at the cell membrane. In ACP that harbors mutations in CTNNB1, $\beta$-catenin shifts into both the cytoplasm and nucleus of the neoplastic cells $(19,20,21,24)$. The development of a mutation-specific antibody (VE1) that recognizes $B R A F$ V600E mutant protein but not WT BRAF protein provides pathologists with another IHC tool to discriminate PCP from ACP and from other entities that are in the differential diagnosis (25). Our study demonstrated a very high concordance between IHC results and genetic mutations in craniopharyngioma (18). Thus, IHC information can be used in diagnostic decision making when needed and when available as pathologists formulate their final diagnostic reports.

In addition to situations where specimens are minute, $B R A F$ VE1 IHC may be useful in the routine evaluation of Rathke's cleft cysts (RCCs) $(17,26,27)$. A recent re-evaluation of 33 suprasellar mass that were diagnosed as RCCs showed that three cases harbored BRAF V600E mutations (27). These cases had an atypical clinical presentation and two had squamous metaplasia. Upon re-evaluation of the pathology and clinical information, these three cases were re-classified as PCP. Hence, determining the BRAF status is likely of significant value when evaluating epithelial suprasellar lesions $(17,26,27)$.

One caveat and challenge of using IHC to identify specimens harboring BRAF V600E mutations is that the VE1 antibody can cross-react with certain BRAF WT tissues. For example, endocrine tissues such as normal pituitary are immunoreactive with the VE1 antibody despite these tissues having WT BRAF (28). The VE1 antibody also cross-reacts with cilia $(17,26,29)$ through recognition of epitopes in the axonemal dyneins of cilia that resemble the BRAF V600E peptide sequence used to generate the VE1 antibody (26). The cytosol of ciliated cells shows variable degrees of positivity (26). Thus, VE1 IHC of RCCs, which has ciliated epithelium, should be interpreted cautiously. In some cases where interpretation of the staining may be uncertain, allele-specific genetic testing for BRAF V600E mutation may be required to support the IHC results $(17,26,27)$. In some institutions allele specific genetic testing may be the preferred diagnostic modality. Because over $90 \%$ of PCPs harbor BRAF V600E mutations, some institutions may find it sufficient to make diagnoses and guide therapy decisions based on review of H\&E stained sections alone.

Currently, the WHO classification of craniopharyngioma does not require mutation assessment using surrogates like IHC or direct genetic testing (1). In time 
though, the classification of craniopharyngioma could have at least four groups: ACP CTNNB1 mutated, adamantinomatous craniopharyngioma CTNNB1 WT, PCP BRAF V600E mutated, and PCP BRAF WT.

It is possible that the WT tumors may have different ways of activating BRAF or $\beta$-catenin that have not yet been identified. Uncovering the genetic drivers of the few CTNNB1 and BRAF WT craniopharyngioma will allow for further refinement of these categories.

Interestingly, a study has suggested that BRAF V600E mutations and mutations in CTNNB1 may co-exist in approximately $10 \%$ of ACP (30). While targeted sequencing from the validation set from our original genomic study did not detect ACP samples with BRAF V600E mutations (18), the possibility of co-occurring mutations is very intriguing and requires further exploration. If co-existence of mutations in craniopharyngioma is confirmed, it will be important to determine if either mutation is clonal or subclonal, the clinical course of such tumors as well as the optimal treatment.

\section{Systemic treatment for BRAF V600E mutated PCP}

While targeting and inhibiting $\beta$-catenin directly remains an unsolved challenge, considerable advances in the treatment of BRAF V600E mutant melanoma provide a paradigm for the targeted therapy of PCP $(31,32)$. Targeted therapy has been successful for treating patients with other BRAF V600E mutated tumors (33) including hairy cell leukemia $(33,34,35,36,37,38,39)$, Erdheim Chester Disease (33, 40), ameloblastoma $(41,42,43)$, and pleomorphic xanthoastrocytoma $(33,44,45,46,47)$.

Using targeted agents that inhibit $B R A F$ and MEK, we recently achieved a dramatic response in a patient with a multiply recurrent $B R A F$ V600E mutated PCP (48). Prior to therapy with $B R A F$ and MEK inhibitors, the patient required several urgent neurosurgical decompressions for a rapidly growing tumor, which had a very large cystic component. The patient suffered from panhypopituitarism and chronic bilateral optic neuropathy. We first treated the patient with the BRAF inhibitor dabrafenib alone. In 17 days, the solid part of the tumor decreased by $50 \%$ and the cystic portion by $70 \%$. Because concomitant inhibition of $B R A F$ and MEK has been shown to reduce the emergence of resistance in melanoma (31), we added trametinib for an additional 14 days. During the treatment the solid part of the tumor decreased by $85 \%$ and the cystic portion by $81 \%$. The size of the cyst may have decreased as the treatment compromised the tumor epithelium and presumably diminished cyst fluid secretion. The residual tumor was resected and then 3 weeks later the patient was administered radiation therapy. Eight months following the radiation therapy, the patient remains without new symptoms (48).

Review of the histology of the specimens that were resected before and after dabrafenib/trametinib treatment revealed a remarkable effect (Fig. 1). The Ki67 proliferation index decreased from over $20 \%$ in the pre-treatment tumor to $<0.5 \%$ in the on-treatment tumor. Radiation therapy was administered 3 weeks after this final on-treatment tumor resection. The combined dabrafenib and trametinib treatment led to a prominent immune response with foamy macrophages engorging the fibrovascular cores and CD8-positive $\mathrm{T}$ cells infiltrating throughout the tumor. This suggests that targeted therapy unleashes a strong anti-tumor immune response in PCP, a phenomenon that also appears to be elicited by BRAF inhibition in melanoma $(49,50,51)$.
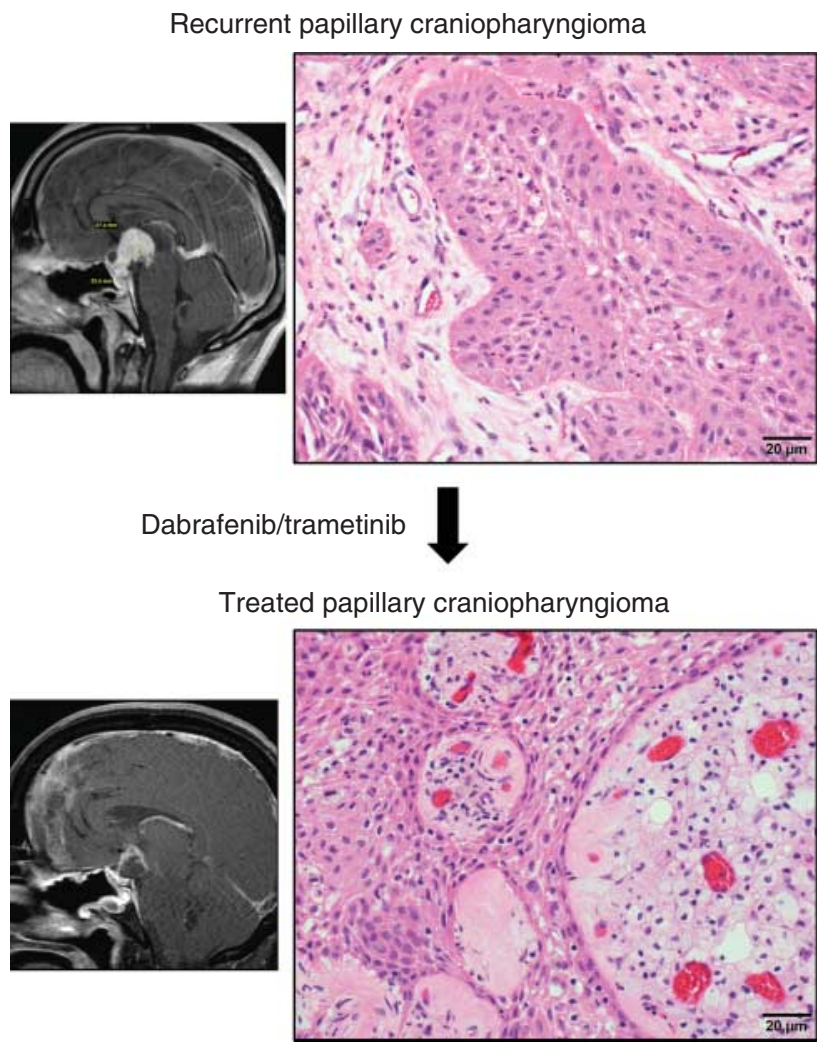

\section{Figure 1}

$\mathrm{H} \& \mathrm{E}$ stained sections of pre- and post-treatment PCP from case reported in Brastianos et al., JNCI 2015 (48). Top panel shows the recurrent tumor. The lower panel shows the tumor following treatment with dabrafenib and trametinib. 
Development of resistance to BRAF and MEK inhibitors is common in patients with melanoma. Whole exome sequencing data from the pre- and on-treatment tumors from our patient did not identify the emergence of any known genetic drivers of $B R A F$ resistance (18). The low frequency of mutations and limited genomic complexity of these tumors suggest that combined therapy may effectively limit the emergence of resistance but high vigilance for the emergence of treatment resistance mechanisms will be required.

The rationale of concomitantly targeting $B R A F$ and MEK for PCP treatment is supported by a recently published report using single agent vemurafenib treatment in a patient with a BRAF V600E mutant PCP (52). Similar to the response observed in our patient, that tumor was also exceptionally responsive to targeted treatment, with a near complete radiological response after 3 months. When vemurafenib was held, however, the tumor re-grew in 6 weeks. Tumor growth was stabilized when vemurafenib was re-administered but tumor progression subsequently ensued. The tumor progression seen in that patient treated with single agent vemurafenib suggests combining BRAF and MEK inhibition will be preferable for prolonged and durable control of tumor growth.

\section{Phase II clinical trial study evaluating the combination of BRAF and MEK inhibition in patients with PCP}

Given these exceptional tumor responses and the consistent occurrence of the BRAF V600E mutation in the vast majority of PCPs, we are now designing a multicenter phase II study evaluating the combination of BRAF and MEK inhibition in patients with PCPs. We will study the effect of dual inhibition because of the improved efficacy of the combination over single agent $B R A F$ inhibitors in other $B R A F$-mutant tumors. As most resistance to singleagent $B R A F$ inhibitors occurs because of reactivation of the RAF-MEK-ERK (MAPK) pathway, the addition of MEK inhibition delays the emergence of resistant clones. Furthermore, the major complication of RAF inhibitor treatment is the development of cutaneous squamous-cell carcinoma. This complication is significantly reduced in patients receiving the combination of dabrafenib and trametinib compared with those receiving single agent treatment alone (31). Systemic treatment will be administered until definitive therapy with surgery or radiation therapy is indicated. Correlative studies will be performed with a focus on obtaining pre- and post-treatment tissue which will be characterized with whole exome sequencing and RNA-sequencing in an attempt to identify potential mutations, genomic aberrations, or transcriptional mechanisms that might render PCP tumors either refractory or resistant to treatment.

\section{Future outlook}

The current standard of care for treating PCP involves surgery and radiation and can lead to substantial morbidity. Therefore, a neo-adjuvant approach for treating these tumors could be of use in selected patient populations. Such strategies are commonly used for prolactin producing pituitary adenomas which are treated with bromocriptine as well as for germ cell tumors. Of note, we were able to detect mutant BRAF V600E DNA circulating in the blood of our exceptional responder patient (48). This finding is encouraging and suggests that confirming the presence of PCP may be achievable through non-invasive "liquid biopsy" methods such as cell-free DNA (cfDNA) detection testing. Our trial will include explorative objectives designed to carefully assess such capabilities. Moreover, the development of validated radiological criteria for discriminating PCP and ACP from one another and from other tumors will be important for evaluating patients with suprasellar masses $(3,53,54,55$, 56). A combination of improved non-invasive diagnostics coupled with effective targeted therapy could provide a new treatment paradigm that in molecularly selected patient populations reduces the morbidities associated with surgery and radiation and improves the outcomes of patients with PCP and other rare brain tumors (57).

\section{Declaration of interest}

The authors declare that there is no conflict of interest that could be perceived as prejudicing the impartiality of the research reported.

\section{Funding}

This work was supported by the National Institutes of Health (K08 NS064168 and K12 CA090354-11), the Brain Science Foundation, the Conquer Cancer Foundation, the American Brain Tumor Association, the Jared Branfman Sunflowers for Life Fund for Pediatric Brain, and Spinal Cancer Research, A Kid's Brain Tumor Cure Foundation, Pedals for Pediatrics and the Clark Family, the Stahl Family Charitable Foundation, the Stop \& Shop Pediatric Brain Tumor Program, and the Pediatric Brain Tumor Clinical and Research Fund.

\section{References}

1 Louis DN, Ohgaki H, Wiestler OD, Cavenee WK. WHO Histological Classification of Tumours of the Central Nervous System. 4th edn, pp 238-240: Lyon: International Agency for Research on Cancer, 2007. 
2 Ostrom QT, Gittleman H, Liao P, Rouse C, Chen Y, Dowling J, Wolinsky Y, Kruchko C \& Barnholtz-Sloan J. CBTRUS statistical report: primary brain and central nervous system tumors diagnosed in the United States in 2007-2011. Neuro-Oncology 201416 (Suppl 4) iv1-i63. (doi:10.1093/neuonc/nou223)

3 Pascual JM, Prieto R \& Carrasco R. Infundibulo-tuberal or not strictly intraventricular craniopharyngioma: evidence for a major topographical category. Acta Neurochirurgica 2011153 2403-2425; discussion 2426. (doi:10.1007/s00701-011-1149-4)

4 Duff J, Meyer FB, Ilstrup DM, Laws ER Jr, Schleck CD \& Scheithauer BW. Long-term outcomes for surgically resected craniopharyngiomas. Neurosurgery 200046 291-302; discussion 302-295. (doi:10.1097/ 00006123-200002000-00007)

5 Barkhoudarian G \& Laws ER. Craniopharyngioma: history. Pituitary 201316 1-8. (doi:10.1007/s11102-012-0402-z)

6 Sterkenburg AS, Hoffmann A, Gebhardt U, Warmuth-Metz M, Daubenbuchel AM \& Muller HL. Survival, hypothalamic obesity, and neuropsychological/psychosocial status after childhood-onset craniopharyngioma: newly reported long-term outcomes. Neuro-Oncology 201517 1029-1038. (doi:10.1093/neuonc/nov044)

7 Stache C, Holsken A, Fahlbusch R, Flitsch J, Schlaffer SM, Buchfelder M $\&$ Buslei R. Tight junction protein claudin-1 is differentially expressed in craniopharyngioma subtypes and indicates invasive tumor growth. Neuro-Oncology 201416 256-264. (doi:10.1093/neuonc/not195)

8 Roemmler-Zehrer J, Geigenberger V, Stormann S, Losa M, Crippa V, Otto B, Bidlingmaier M, Dimopoulou C, Stalla GK \& Schopohl J. Food intake regulating hormones in adult craniopharyngioma patients. European Journal of Endocrinology 2014170 627-635. (doi:10.1530/ EJE-13-0832)

9 Pickering L, Jennum P, Gammeltoft S, Poulsgaard L, Feldt-Rasmussen U $\&$ Klose M. Sleep-wake and melatonin pattern in craniopharyngioma patients. European Journal of Endocrinology 2014170 873-884. (doi:10.1530/EJE-13-1025)

10 Ogawa Y, Kawaguchi T \& Tominaga T. Outcome and mid-term prognosis after maximum and radical removal of craniopharyngiomas with the priority to the extended transsphenoidal approach - a single center experience. Clinical Neurology and Neurosurgery 2014125 41-46. (doi:10.1016/j.clineuro.2014.07.014)

11 Jahangiri A, Wagner J, Han SW, Zygourakis CC, Han SJ, Tran MT, Miller LM, Tom MW, Kunwar S, Blevins LS Jr et al. Morbidity of repeat transsphenoidal surgery assessed in more than 1000 operations. Journal of Neurosurgery 2014121 67-74. (doi:10.3171/2014.3. JNS131532)

12 Liubinas SV, Munshey AS \& Kaye AH. Management of recurrent craniopharyngioma. Journal of Clinical Neuroscience 201118 451-457. (doi:10.1016/j.jocn.2010.10.004)

13 Hankinson TC, Palmeri NO, Williams SA, Torok MR, Serrano CA, Foreman NK, Handler MH \& Liu AK. Patterns of care for craniopharyngioma: survey of members of the american association of neurological surgeons. Pediatric Neurosurgery 201349 131-136. (doi:10.1159/000357783)

14 Crotty TB, Scheithauer BW, Young WF Jr, Davis DH, Shaw EG, Miller GM \& Burger PC. Papillary craniopharyngioma: a clinicopathological study of 48 cases. Journal of Neurosurgery 199583 206-214. (doi:10.3171/jns.1995.83.2.0206)

15 Giangaspero F, Burger PC, Osborne DR \& Stein RB. Suprasellar papillary squamous epithelioma ("papillary craniopharyngioma"). American Journal of Surgical Pathology 19848 57-64. (doi:10.1097/ 00000478-198401000-00006)

16 Zada G, Lin N, Ojerholm E, Ramkissoon S \& Laws ER. Craniopharyngioma and other cystic epithelial lesions of the sellar region: a review of clinical, imaging, and histopathological relationships. Neurosurgical Focus 201028 E4. (doi:10.3171/2010.2.FOCUS09318)

17 Kim JH, Paulus W \& Heim S. BRAF V600E mutation is a useful marker for differentiating Rathke's cleft cyst with squamous metaplasia from papillary craniopharyngioma. Journal of Neuro-Oncology 2015123 189-191. (doi:10.1007/s11060-015-1757-6)

18 Brastianos PK, Taylor-Weiner A, Manley PE, Jones RT, Dias-Santagata D, Thorner AR, Lawrence MS, Rodriguez FJ, Bernardo LA, Schubert L et al. Exome sequencing identifies BRAF mutations in papillary craniopharyngiomas. Nature Genetics 201446 161-165. (doi:10.1038/ng.2868)

19 Martinez-Barbera JP \& Buslei R. Adamantinomatous craniopharyngioma: pathology, molecular genetics and mouse models. Journal of Pediatric Endocrinology \& Metabolism 201528 7-17. (doi:10.1515/jpem2014-0442)

20 Martinez-Barbera JP. Molecular and cellular pathogenesis of adamantinomatous craniopharyngioma. Neuropathology and Applied Neurobiology 201541 721-732. (doi:10.1111/nan.12226)

21 Gaston-Massuet C, Andoniadou CL, Signore M, Jayakody SA, Charolidi N, Kyeyune R, Vernay B, Jacques TS, Taketo MM, Le Tissier P et al. Increased wingless (Wnt) signaling in pituitary progenitor/stem cells gives rise to pituitary tumors in mice and humans. PNAS $2011 \mathbf{1 0 8}$ 11482-11487. (doi:10.1073/pnas.1101553108)

22 Sekine S, Shibata T, Kokubu A, Morishita Y, Noguchi M, Nakanishi Y, Sakamoto M \& Hirohashi S. Craniopharyngiomas of adamantinomatous type harbor $\beta$-catenin gene mutations. American Journal of Pathology 2002161 1997-2001. (doi:10.1016/S0002-9440(10)64477-X)

23 Buslei R, Nolde M, Hofmann B, Meissner S, Eyupoglu IY, Siebzehnrubl F, Hahnen E, Kreutzer J \& Fahlbusch R. Common mutations of $\beta$-catenin in adamantinomatous craniopharyngiomas but not in other tumours originating from the sellar region. Acta Neuropathologica 2005109 589-597. (doi:10.1007/s00401-005-1004-x)

24 Hofmann BM, Kreutzer J, Saeger W, Buchfelder M, Blumcke I, Fahlbusch R \& Buslei R. Nuclear $\beta$-catenin accumulation as reliable marker for the differentiation between cystic craniopharyngiomas and rathke cleft cysts: a clinico-pathologic approach. American Journal of Surgical Pathology 200630 1595-1603. (doi:10.1097/01.pas. $0000213328.64121 .12)$

25 Capper D, Preusser M, Habel A, Sahm F, Ackermann U, Schindler G, Pusch S, Mechtersheimer G, Zentgraf H \& von Deimling A. Assessment of BRAF V600E mutation status by immunohistochemistry with a mutation-specific monoclonal antibody. Acta Neuropathologica 2011 122 11-19. (doi:10.1007/s00401-011-0841-z)

26 Jones RT, Abedalthagafi MS, Brahmandam M, Greenfield EA, Hoang MP, Louis DN, Hornick JL \& Santagata S. Cross-reactivity of the BRAF VE1 antibody with epitopes in axonemal dyneins leads to staining of cilia. Modern Pathology 201528 596-606. (doi:10.1038/ modpathol.2014.150)

27 Schweizer L, Capper D, Holsken A, Fahlbusch R, Flitsch J, Buchfelder M, Herold-Mende C, von Deimling A \& Buslei R. BRAF V600E analysis for the differentiation of papillary craniopharyngiomas and Rathke's cleft cysts. Neuropathology and Applied Neurobiology 201441 733-742. (doi:10.1111/nan.12201)

28 Mordes DA, Lynch K, Campbell S, Dias-Santagata D, Nose V, Louis DN \& Hoang MP. VE1 antibody immunoreactivity in normal anterior pituitary and adrenal cortex without detectable BRAF V600E mutations. American Journal of Clinical Pathology 2014141 811-815. (doi:10.1309/AJCP37TLZLTUAOJL)

29 Bosmuller H, Fischer A, Pham DL, Fehm T, Capper D, von Deimling A, Bonzheim I, Staebler A \& Fend F. Detection of the BRAF V600E mutation in serous ovarian tumors: a comparative analysis of immunohistochemistry with a mutation-specific monoclonal antibody and allele-specific PCR. Human Pathology 201344 329-335. (doi:10.1016/j.humpath.2012.07.010)

30 Larkin SJ, Preda V, Karavitaki N, Grossman A \& Ansorge O. BRAF V600E mutations are characteristic for papillary craniopharyngioma and may coexist with CTNNB1-mutated adamantinomatous craniopharyngioma. Acta Neuropathologica 2014127 927-929. (doi:10.1007/ s00401-014-1270-6)

31 Flaherty KT, Infante JR, Daud A, Gonzalez R, Kefford RF, Sosman J, Hamid O, Schuchter L, Cebon J, Ibrahim N et al. Combined BRAF and 
MEK inhibition in melanoma with BRAF V600 mutations New England Journal of Medicine 2012367 1694-1703. (doi:10.1056/ NEJMoa1210093)

32 Flaherty KT, Puzanov I, Kim KB, Ribas A, McArthur GA, Sosman JA, O'Dwyer PJ, Lee RJ, Grippo JF, Nolop K et al. Inhibition of mutated, activated BRAF in metastatic melanoma. New England Journal of Medicine 2010363 809-819. (doi:10.1056/NEJMoa1002011)

33 Hyman DM, Puzanov I, Subbiah V, Faris JE, Chau I, Blay JY, Wolf J, Raje NS, Diamond EL, Hollebecque A et al. Vemurafenib in multiple nonmelanoma cancers with BRAF V600 mutations. New England Journal of Medicine 2015373 726-736. (doi:10.1056/NEJMoa1502309)

34 Maevis V, Mey U, Schmidt-Wolf G \& Schmidt-Wolf IG. Hairy cell leukemia: short review, today's recommendations and outlook. Blood Cancer Journal 20144 e184. (doi:10.1038/bcj.2014.3)

35 Peyrade F, Re D, Ginet C, Gastaud L, Allegra M, Ballotti R, Thyss A, Zenz T, Auberger P \& Robert G. Low-dose vemurafenib induces complete remission in a case of hairy-cell leukemia with a V600E mutation. Haematologica 201398 e20-e22. (doi:10.3324/haematol. 2012.082404)

36 Munoz J, Schlette E \& Kurzrock R. Rapid response to vemurafenib in a heavily pretreated patient with hairy cell leukemia and a BRAF mutation. Journal of Clinical Oncology 201331 e351-e352. (doi:10.1200/ JCO.2012.45.7739)

37 Follows GA, Sims H, Bloxham DM, Zenz T, Hopper MA, Liu H, Bench A, Wright P, Van't Veer MB \& Scott MA. Rapid response of biallelic BRAF V600E mutated hairy cell leukaemia to low dose vemurafenib. British Journal of Haematology 2013161 150-153. (doi:10.1111/bjh. 12201)

38 Dietrich S, Hullein J, Hundemer M, Lehners N, Jethwa A, Capper D, Acker T, Garvalov BK, Andrulis M, Blume $\mathrm{C}$ et al. Continued response off treatment after BRAF inhibition in refractory hairy cell leukemia. Journal of Clinical Oncology 201331 e300-e303. (doi:10.1200/JCO.2012. 45.9495)

39 Dietrich S, Glimm H, Andrulis M, von Kalle C, Ho AD \& Zenz T. BRAF inhibition in refractory hairy-cell leukemia. New England Journal of Medicine 2012366 2038-2040. (doi:10.1056/NEJMc1202124)

40 Haroche J, Cohen-Aubart F, Emile JF, Maksud P, Drier A, Toledano D, Barete S, Charlotte F, Cluzel P, Donadieu J et al. Reproducible and sustained efficacy of targeted therapy with vemurafenib in patients with BRAFV600E-mutated erdheim-chester disease. Journal of Clinical Oncology 201433 411-418. (doi:10.1200/JCO.2014.57.1950)

41 Sweeney RT, McClary AC, Myers BR, Biscocho J, Neahring L, Kwei KA, $\mathrm{Qu} \mathrm{K}$, Gong X, Ng T, Jones CD et al. Identification of recurrent SMO and BRAF mutations in ameloblastomas. Nature Genetics 201446 722-725. (doi:10.1038/ng.2986)

42 Kaye FJ, Ivey AM, Drane WE, Mendenhall WM \& Allan RW. Clinical and radiographic response with combined BRAF-targeted therapy in stage 4 ameloblastoma. Journal of the National Cancer Institute $2015 \mathbf{1 0 7}$ 378. (doi:10.1093/jnci/dju378)

43 Gomes CC, Diniz MG \& Gomez RS. Progress towards personalized medicine for ameloblastoma. Journal of Pathology 2014232 488-491. (doi:10.1002/path.4331)

44 MacConaill LE, Campbell CD, Kehoe SM, Bass AJ, Hatton C, Niu L, Davis M, Yao K, Hanna M, Mondal C et al. Profiling critical cancer gene mutations in clinical tumor samples. PLOS ONE 20094 e7887. (doi:10.1371/journal.pone.0007887)
45 Lee EQ, Ruland S, LeBoeuf NR, Wen PY \& Santagata S. Successful treatment of a progressive BRAF V600E-mutated anaplastic pleomorphic xanthoastrocytoma with vemurafenib monotherapy. Journal of Clinical Oncology 2014. In press. (doi:10.1200/JCO.2013. 51.1766)

46 Dias-Santagata D, Lam Q, Vernovsky K, Vena N, Lennerz JK, Borger DR, Batchelor TT, Ligon KL, Iafrate AJ, Ligon AH et al. BRAF V600E mutations are common in pleomorphic xanthoastrocytoma: diagnostic and therapeutic implications. PLOS ONE 20116 e17948. (doi:10.1371/journal.pone.0017948)

47 Chamberlain MC. Salvage therapy with BRAF inhibitors for recurrent pleomorphic xanthoastrocytoma: a retrospective case series. Journal of Neuro-Oncology 2013114 237-240. (doi:10.1007/s11060-013-1176-5)

48 Brastianos PK, Shankar GM, Gill CM, Taylor-Weiner A, Nayyar N, Panka DJ, Sullivan RJ, Frederick DT, Abedalthagafi M, Jones PS et al. Dramatic response of BRAF V600E mutant papillary craniopharyngioma to targeted therapy. Journal of the National Cancer Institute 2016 188 djv310. (doi:10.1093/jnci/djv310)

49 Frederick DT, Piris A, Cogdill AP, Cooper ZA, Lezcano C, Ferrone CR, Mitra D, Boni A, Newton LP, Liu C et al. BRAF inhibition is associated with enhanced melanoma antigen expression and a more favorable tumor microenvironment in patients with metastatic melanoma. Clinical Cancer Research 201319 1225-1231. (doi:10.1158/1078-0432. CCR-12-1630)

50 Cooper ZA, Juneja VR, Sage PT, Frederick DT, Piris A, Mitra D, Lo JA, Hodi FS, Freeman GJ, Bosenberg MW et al. Response to BRAF inhibition in melanoma is enhanced when combined with immune checkpoint blockade. Cancer Immunology Research 20142 643-654. (doi:10.1158/ 2326-6066.CIR-13-0215)

51 Wilmott JS, Long GV, Howle JR, Haydu LE, Sharma RN, Thompson JF, Kefford RF, Hersey P \& Scolyer RA. Selective BRAF inhibitors induce marked T-cell infiltration into human metastatic melanoma. Clinical Cancer Research 201218 1386-1394. (doi:10.1158/1078-0432.CCR11-2479)

52 Aylwin SJ, Bodi I \& Beaney R. Pronounced response of papillary craniopharyngioma to treatment with vemurafenib, a BRAF inhibitor. Pituitary 2015. In press. (doi:10.1007/s11102-015-0663-4)

53 Sartoretti-Schefer S, Wichmann W, Aguzzi A \& Valavanis A. MR differentiation of adamantinous and squamous-papillary craniopharyngiomas. AJNR. American Journal of Neuroradiology 199718 77-87.

54 Pascual JM, Prieto R, Castro-Dufourny I \& Carrasco R. Topographic diagnosis of papillary craniopharyngiomas: the need for an accurate MRI-surgical correlation. AJNR. American Journal of Neuroradiology 2015 36 E55-E56. (doi:10.3174/ajnr.A4441)

55 Lee HJ, Wu CC, Wu HM, Hung SC, Lirng JF, Luo CB, Chang FC \& Guo WY. Pretreatment diagnosis of suprasellar papillary craniopharyngioma and germ cell tumors of adult patients. AJNR. American Journal of Neuroradiology 201536 508-517. (doi:10.3174/ajnr.A4142)

56 Pascual JM, Gonzalez-Llanos F, Barrios L \& Roda JM. Intraventricular craniopharyngiomas: topographical classification and surgical approach selection based on an extensive overview. Acta Neurochirurgica 2004146 785-802. (doi:10.1007/s00701-004-0295-3)

57 Brastianos PK, Horowitz PM, Santagata S, Jones RT, McKenna A, Getz G, Ligon KL, Palescandolo E, Van Hummelen P, Ducar MD et al. Genomic sequencing of meningiomas identifies oncogenic SMO and AKT1 mutations. Nature Genetics 201345 285-289. (doi:10.1038/ng.2526)
Received 27 September 2015

Revised version received 26 October 2015

Accepted 12 November 2015 